\title{
The Importance of Fecal Transplantation in Personalized Medicine
}

\section{Kişiselleştirilmiş Tıpta Fekal Transplantasyonun Önemi}

\author{
Ender COŞKUNPINAR ${ }^{1}$ iD, Fagan ÍSLAMZADE ${ }^{1}$ iD, Elif Pelin YLMAZ ${ }^{1}$ iD, Ceyda HAYRETDAĞ ORS² id, \\ Hüseyin ADAK ${ }^{1}$ iD, Ahmet YEŞILTEPE ${ }^{1}$ id, Seyithan TÜRKSOYLU ${ }^{1}$ iD, Ahmet Cem DURAL ${ }^{3}$ iD \\ ${ }^{1}$ Department of Medical Biology, Health Sciences University School of Medicine, İstanbul, Turkey \\ ${ }^{2}$ Department of Anatomy, Health Sciences University School of Medicine, İstanbul, Turkey \\ ${ }^{3}$ Department of General Surgery, Dr. Sadi Konuk Training and Research Hospital Health Sciences University School of Medicine, \\ İstanbul, Turkey
}

\section{ABSTRACT}

It is known that intestinal microbiota feeding habits in healthy humans have a direct effect on the formation of intestinal microbiota, while simultaneously playing the most important role in the development of the immune system. Our aim in this study was to investigate the effectiveness of this treatment method.

Although there is no consensus on how to prepare a fecal transplantation material, the "Amsterdam protocol" is the most prevalent. The solution prepared according to this protocol is suspended using a filter or steel strainer to remove particles. These suspensions are used by injectors. Different diluent materials have been used in various studies, and it is recommended to use non-bacteriostatic $0.9 \%$ saline solution. Fecal transplantation was successfully applied to cases of subjects between 2 and 90 years of age when the work done up to these days was examined. The most common indication in childhood and geriatric population is pseudomembranous enterocolitis; inflammatory bowel disease, irritable bowel syndrome, chronic diarrhea/constipation, solitary rectal ulcer, and other chronic colon ulcers are associated with the gastrointestinal tract in adulthood. Studies demonstrating the efficacy of fecal transplantation are often focused on the treatment of Clostridium difficile infection, which is resistant to treatment or recurrence. Successful results obtained inspired many of the studies that followed fecal transplantation, and now fecal transplantation has been started to treat many diseases such as inflammatory bowel disease, irritable colon syndrome, chronic constipation, and non-alcoholic fatty liver disease, especially pseudomembranous enterocolitis due to C. difficile.

If we think that our microbiota is a person-specific organ such as a fingerprint or eye retina, treatment of microbiota diseases will automatically differ from person to person. However, all characteristics such as age, donor selection, post-transplantation process management, environmental factors, especially the diseases that recipients and donors carry, amount of drug given during preparation process, and content of the material to be transplanted show how individualized treatment of fecal transplantation is. Keywords: Personalized medicine, fecal transplantation, neurodegenerative diseases

\section{öz}

Sağlıklı İnsanlarda İntestinal Mikrobiyota Beslenme alıșkanlıklarının, intestinal mikrobiyotanın oluşumu üzerine direkt etkili olduğu, aynı zamanda da immün sistem gelişiminde en önemli rolü oynadığı bilinmektedir. Bu çalısmadaki amacımı bu tedavi yönteminin etkinliğinin araştıılmasıdır.

Fekal Transplantasyon materyalinin hazırlanması ile ilgili bir fikir birliği olmamasına rağmen en çok "Amsterdam protokolü” ön planda tutulmaktadır. Bu protokole göre hazırlanan solüsyon partikülleri temizlemek için filtre veya çelik süzgeç kullanılarak süspansiyon haline getirilir. Bu süspansiyonlar enjektörlere konularak kullanılır. Çeşitli çalışmalarda farklı dilüe edici maddeler kullanılmış olup önerilen sulandırıcı non-bakteriostatik \%0,9’luk serum fizyolojiktir.

Fekal Transplantasyon günümüze kadar yapılan çalışmalara bakıldığında, 2 ila 90 yaş arasındaki olgulara başarı ile uygulanmıştır. Çocukluk çağında ve geriatrik popülasyonda en sık endikasyon psödomembranöz enterokolit iken; erişkin yaşlarda gastrointestinal sistemle ilgili olarak İnflavatuvar Bağırsak Hastalığı, İrritabl Bağırsak Sendromu kronik diyare/konstipasyon, soliter rektal ülser ve diğer kronik kolon ülserleridir. Fekal transplantasyonun etkinliğini gösteren çalışmalar sıklıkla tedaviye dirençli ya da tekrarlayan Clostridium difficile enfeksiyonu tedavisine odaklı çalışmalardır. Alınan başarilı sonuçlar daha sonra Fekal Transplantasyonun kullanıldığı birçok çalışmaya ilham kaynağı olmuş ve bugün Fekal Transplantasyonun başta Clostridium difficile'e bağlı psödomembranöz enterokolit olmak üzere, inflamatuvar bağırsak hastalığı, irritabl kolon sendromu, kronik konstipasyon ve Alkolik Olmayan Yağlı Karaciğer Hastalığı gibi birçok hastalığın tedavisinde kullanılmaya başlanmıştır.

Mikrobiyotamızın parmak izi, retina gibi her kişiye özgü bir organımız olduğunu düşünürsek mikrobiyota hastalıklarının tedavisi de otomatik olarak kişiden kişiye farklılık gösterecektir. Bununla birlikte yaş, donör seçimi, transplantasyon sonrası sürecin yönetimi, çevresel faktörler, özellikle alıcı ve donörün taşıdığı hastalıklar hazırlık sürecinde verilecek ilaç miktarı, transplante edilecek materyaldeki içerik gibi özelliklerin tümü fekal transplantasyon uygulamasının ne kadar kişiye özgü bir tedavi olduğunu gösterir.

Anahtar sözcükler: Kişiselleştirilmiş tıp, fekal transplantasyon, nörodejeneratif hastalıklar

Cite this article as: Coskunpinar E, i̇slamzade F, Yılmaz EP, Hayretdag Ors C, Adak H, Yeşiltepe A, et al. The Importance of Fecal Transplantation in Personalized Medicine. Bezmialem Science 2018; 6(4): 305-11. 


\section{Introduction}

There are 300500 kinds of microorganisms in human stomach, and the amount of bacteria per gram of stool is about 1012 (1). Intestinal microbiota; It plays an important role in many cases in humans, especially in nutrition, metabolic, physiological and immunologic. The intestinal system microbiology has become the focus of attention due to all these features and has been the subject of many studies done in recent years. It is understood that gastrointestinal system fluorescence is closely related to obesity, metabolic syndrome, type 2 diabetes and atherosclerosis, which are the most important causes of mortality and morbidity today besides physiological conditions $(2,3)$. In Healthy Humans it is known that intestinal microbiota eating habits play a major role in the development of the intestinal microbiota, as well as in the development of the immune system. Except its immune system role, Intestinal microbiota is effective in many metabolic events. Today, gastrointestinal system microbiota is known to be effective in the pathogenesis of obesity, diabetes mellitus, atherosclerosis and non-alcoholic fatty liver disease $(4,5)$. In recent years, it has been understood that intestinal microbiota actually acts like an "organ", which has important functions in systemic and mucosal immun system functions in many metabolic events. Microorganisms in the microbiota include carbohydrates digestion, energy storage, immunological functions, and protection against the invasion of pathogenic bacteria. Today, we know that some antimicrobials have serious effects on the intestinal microbiota. For example, the accepted view for Clostridium difficile ( $C$. difficile) is the use of broadspectrum antibiotics, impaired intestinal microbiota balance, and triggering of the process leading to infections of pathogenic $C$. difficile strains in the intestines (1).

Considering this mechanism, fecal transplant studies are on the agenda. Fecal microbiota transplantation (FMT) is the process of fecal bacteriotherapy, fecal transfusion and gaita transplantation by other names in the terminology, the placement of gaita from a healthy donor into the gastrointestinal tract of the recipient.

\section{Steps in Fecal Transplantation Application}

\section{Who can be selected?}

Taking into account the perception of the intestinal flora and the environment in which the person lives, taking the feces of the individuals the patient is in contact with daily will minimize the risk of the new pathogen. For this reason, donors should usually be selected from patients wife, close relatives or immediate vicinity. Thus, new pathogen transfer to the recipient is relatively inhibited (6). The choice of donor for the treatment of the illness has a slightly higher proportion in close relatives (93\%) than foreigners (84\%). However, there is no statistically significant difference between these rates (7). In studies with random donor selection, the results were close to those obtained from related donors (8). Donor gender is not effective in the success of cure (9).

\section{Things to be aware of at the Buyer and Donor}

Donors for FMT need to be examined in detail; 1. A history of travel to endemic diarrhea region, 2. Sex experience, 3. Preoperative history, 3. Blood transfusion, 4. Autoimmune and metabolic disease in the family of a donor, 5 . Whether malignancy exists in first and second degree relatives should be questioned (10). When a donor is selected, screening should be done according to the Amsterdam protocol (9-12). Important points to note in the history are; 1 . Has normal body mass index $\left(18-25 \mathrm{~kg} / \mathrm{m}^{2}\right) 2$. Has he received antibiotic and continuous proton pump inhibitor in the last 3 months? 3 . Do you have tattoos, piercings and prison life in the last 3 months? 4. Do you have sex and IV medication with highrisk people in the last 3 months? 5. Is there irritable bowel syndrome, inflammatory bowel disease (Crohn's and UC), Type 1 diabetes mellitus, Hashimato hypothyroidism, Graves hyperthroidism, rheumatoid arthritis, celiac disease? 6. Are there chronic diarrhea / constipation, colorectal polyps and cancer? 7. Immunocompromise? (Is there immunosuppression or chemotherapy?) 8. Is there any chronic fatigue syndrome? 9. Are there atopy, food allergies? The specified properties must be questioned in detail. In addition, the donor should examine both the gaita and the blood. In the donor's stomach; Clostridium difficile toxin, Cryptosporidium, bacteria; Helicobacter pylori antigen, Yersinia, Campylobacter, Shigella, Salmonella, Enteropathogenic Escherichia coli, viruses; Rotavirus, Adenovirus, Enterovirus, Parechovirus, Sapovirus, Norovirus, parasites; Astroviruses and Giardia should be investigated.

\section{How Should the Donor be Prepared in the Fecal Trans- plantation Process?}

The preparation of the patient to be transplanted varies according to the type of transplantation. Although not a published guide in this regard, it is seen in the made works that high enema is performed with laxative and/or purgative (polyethylene glycol, senna glycosides etc.) in the case of Fecal Transplantation (FT) with colonoscopy or enema and fecal transplant. There is no need for a special preparation method in patients who will be treated with nazoduodenal or nasojejunal probe. In addition, metronidazole, rifampicin has been reported to be effective in ulcerative colitis for 7-10 days before FT. It is recommended to take a light laxative before bed. Then the feces are transplanted. On the other hand, there are studies in which Saccharomyces boulardii treatment is administered for 60 days after FT (11). In another study, loperamide treatment was used immediately after FT to reduce colon peristalsis and allow the transplantation material to more contact the colon mucosa (13).

\section{How Should the Fecal Transplantation Material be Pre- pared?}

Although there is no consensus on this issue, the Amsterdam protocol is mostly held on the frontline and is being prepared accordingly. The solution prepared according to this protocol is suspended using a filter or steel strainer to remove large particles. These suspensions are used by injectors $(9,12)$. 


\section{Which Diluent Should be Used?}

Different diluent materials were used in various studies and it is a recommended non-bacteriostatic $0.9 \%$ saline solution. Yoghurt, buttermilk, milk, water and eggs are also used (14, 15). Improvements were more frequent in the infusions made with distilled water prepared suspensions than those prepared with saline, but relapse was higher. Similarly, it is seen that relapse was higher in high-volume suspension infusions.

\section{How much Gaita and Diluent are Needed?}

The amount of feces used changes the success and recurrence rate of the treatment. If less than $200 \mathrm{~mL}$ of fecal material is given; Treatment success rate is $80 \%$ and recurrence rate is $6.2 \%$. When more than $500 \mathrm{ml}$ of fecal material is given, the success rate of treatment increases to $97.3 \%$ and recurrence rate decreases to $4.7 \%$. When the number of infusions was compared, success in a study was $73 \%$, whereas in a different study this rate was $91 \%$ and the success rate was not related to the number of infusions (16). 50-60 gr feces for gastroscopy should be $250 \mathrm{ml}$ diluent, 200-300 gr feces for colonoscopy should be $500 \mathrm{ml}$ diluent. There was no significant difference in the work done with both fresh and frozen stools. Fresh gaita should be given within 8 hours. However, similar results were obtained with transplantation of fecal specimens stored frozen at $-20^{\circ} \mathrm{C}$ for $1-4$ weeks. In other words, when the gaita is solved and processed, the success rate of fresh stool treatment was $92 \%$ while the success rate of treatment in frozen gaita was 90\% (17).

\section{The Ways in Which Faecal Material is Transplanted and the Differences Between Them}

Fecal material for transplantation can be infused from various pathways. In 1998, enema was the most commonly used method. In 2000, colonoscopy together with enema was the most commonly used method for FT. At present, approximately $75 \%$ of enema and colonoscopy cases are used in FT studies, whereas nasogastric/duodenal probe or esophagogastroduodenoscopy method is preferred in $25 \%$ of cases. It has been reported that there is no difference between the methods for upper GI in terms of success rate. In the lower GIS, the fecal transplantation material can only reach splenic flexure with enema, whereas colonoscopy can be used to inoculate the entire colon and ileum with transplantation material. (18). There is no comparative study of the way in which the application is made. Numerous studies have been published that conflicting results. In fact, there are no major differences between the results. The best and most effective route is the route chosen for the anatomical location of the disease. For example, the best way to treat metabolic (insulin resistance, celiac, small bowel) diseases is the duodenal infusion route. In colonoscopy, the fecal material infiltrates up to the ileum and/or the terminal ileum is the best result of FT. Whichever way it is given, the material needs to be kept at least 4 hours in order for the transplantation to be effective. This requires ending the procedure by tilting the patient to the left side and aspirating the air from the colon (18).

\section{Results}

Advantages and risks of the method that has been determined up to now in FT: FT has been successfully applied to cases between 2 and 90 years old, when the work done up to date is considered. The most common indication in childhood and geriatric population is pseudomembranous enterocolitis; Inflammatory bowel disease (IBD), Irritable bowel syndrome (IBS), chronic diarrhea/constipation, solitary rectal ulcer and other chronic colon ulcers associated with the gastrointestinal tract in adult ages. Studies demonstrating the efficacy of faecal transplantation are often focused on the treatment of $C$. difficile infection, which is resistant to treatment or recurrence (19). The successful results were inspired by many of the studies that followed FT, and today FT has been used to treat IBD, IBS, chronic constipation and non-alcoholic fatty liver disease (NAFLD) have been started to be used in the treatment of many diseases (18). In a study researchers have become the gold standard for treatment with reflux C. difficile infection treatment with a cure rate of over $90 \%$ nowadays after the first successful results of fecal transplantation with enema in 4 cases with pseudomemannular enterocolitis for the first time (20). Due to pseudomembranous enterocolitis due to $C$. difficile, 77 patients with FT were followed for 3 months and the primary cure rate was $91 \%$. The cure rate was assessed as $98 \%$ in those who were not able to achieve success with 2 nd and 3rd FT and had antibiotic treatment added. In addition, after FT, some changes in bowel habits were detected in these patients within 1 week. Main observed changes; constipation and diarrhea, bloating, belching, abdominal cramps, gas, peritonitis type findings and fever. In 77 of the 77 patients studied, rheumatoid arthritis, Sjögren's syndrome, idiopathic thrombocytopenic purpura and peripheral neuropathy, Some side effects have been observed but these have not been fully associated with FT (21). In 2009, Van Nood and colleagues examined 16 studies from 1958 to 2008 in the literature review of publications reporting fecal bacteriotherapy. In this study, treatment success in 159 cases treated with recurrent fecal transplantation with $C$. difficile was reported as $91 \%$ (22).

Rohlke F et al. (23) reported that in 2010, 19 patients with recurrent $C$. difficile infection were infected with non-donor colon through colonoscopy and cured in all patients between 6 months and 5 years of follow-up. In a retrospective study involving 18 cases in 2003, patients were treated with fecal transplantation, and each patient received a 30 -gram single fecal infusion via nasogastric tube. Significant improvement in symptoms was achieved at 12 to 24 hours after treatment, and treatment success was reported as $94 \%$ (6).

\section{Usage Areas and Results of Treatment with FT}

\section{Effect on Neurological Diseases}

\section{Multiple Sclerosis and Myoclonic Dystonia}

Recently, there have been publications in the literature about the usage and success of this treatment method in relation to neurodegenerative diseases. In one of these reports, 3 patients 
with multiple sclerosis who had undergone FMT due to constipation lost their neurological symptoms and their quality of life improved. In another publication, a young female patient who has been diagnosed with myoclonic dystonia and chronic diarrhea since the age of 6 years immediately after the administration of FMT has reported loss of diarrhea complaints and a $90 \%$ reduction in the symptoms of myoclonic dystonia (24).

\section{Autism Spectrum Disorder}

Autism spectrum disorder is the most common neurodevelopmental disability after mental disability today. There is a great deal of research done in this regard. Increased neuroinflammatory markers were found in mice that exhibited autistic behavior due to prenatal valproic acid administration in one of these studies $(25,26)$. In a study conducted by $\mathrm{H}$ siao et al. (27), mice exhibiting autistic behavior were treated with Bacteroides fragilis. It has been reported that impaired permeability of mouse intestine has been repaired by Bacteroides fragilis due to the increase in tightly linked protein expression and cytokine production. In addition, the level of 4-ethyl-phenylsulfate, a bacterial metabolite, has been found to increase in the serum of autistic mice. This material caused autistic behavior when applied to normal mice. Although no clinical studies have been conducted with FMT in autistic patients, Clostridium species are reported to be more common in children with autistic children than in healthy children (27, 28).

\section{Parkinson's Disease}

In Parkinson's disease, the onset of constipation complaints has been reported to occur about 10 years before the onset of motor symptoms, which has led to an interpretation that the disease has started in the intestine (24). It has been reported that a patient with a Parkinson's disease complaining of chronic insufficiency was treated with antibiotic therapy (vancomycin, metronidazole and colchicine) and neurological symptoms completely disappeared after 10 months of antibiotic therapy (29). Even these few examples suggest that FMT will be among the treatment protocols at a very short time.

There are studies showing that fecal transplantation may be effective in the treatment of various diseases besides gastroenteritis. Fecal transplantation procedure has also been reported to be used in inflammatory bowel diseases and irritable bowel syndrome. Studies report $100 \%$ resolution without relapse or death $(30,31)$. In 2003, Borody et al. Tested fecal transplantation on ulcerative colitis patients. Six patients with ulcerative colitis with severe recurrent symptoms who were diagnosed by colonoscopy and histology were treated with recurrent retention enema for 5 days and the symptoms were completely recovered despite the discontinuation of ulcerative colitis in all patients. Clinical, colonoscopic or histologic ulcerative colitis has not been observed in any case for 1-13 years follow-up, although they do not receive medical treatment (30). Borody is also working on the use of fecal transplantation in the treatment of Parkinson's disease. In 2010, Anne Vrieze and col- leagues reported the results of fecal transplantation in patients with metabolic syndrome. 18 newly diagnosed men with metabolic syndrome underwent fecal transplantation. The study was double-blind, randomized controlled and their feces were transplanted to half of the cases, while the feces from the poor donors were transplanted. It has been reported that fasting triglyceride levels fall significantly in the cases transplanted to the donor site. Also in this group, the peripheral and hepatic insulin sensitivity improved significantly at the end of the sixth week following transplantation $(18,32)$. This is a very important result especially for obese cases. In Crohn's disease, the number of studies related to FT is relatively small and there are conflicting results. There are reports reporting complete remission with FT for up to 18 months in the investigations, and remission reports for 4 months in refractory Crohn's disease cases with sulfosalazine and steroid treatment. In IBS, there are studies reporting that FT provides complete recovery in 36\% of cases and control symptoms in 16\% (33). In chronic constipation, more successful results were obtained with FT. With colonoscopic FT performed in 45 patients, the frequency of defecation improved in $89 \%$ of the cases and the abdominal pain returned to normal. Up to $2 \%$ of these cases had normal defecation without the need for laxatives in $60 \%$ of cases (34).

It is also noteworthy that FT as a primary gastrointestinal system disease in Gastrointestinal Non-Systemic Diseases is being investigated in the treatment of gastrointestinal system diseases while it also improves in other diseases accompanied with gastrointestinal system diseases, especially neurological diseases. In neurological diseases, such as autism, myoclonic dystonia and chronic fatigue syndrome, the majority are still on a case-by-case basis, but the prospect of a significant improvement in symptoms of FT is impaired (35). The increased frequency of symptoms associated with the gastrointestinal system, especially in autistic children, and the increased use of broad spectrum antibiotics that affect intestinal microbiota in these conditions suggests that intestinal microbiota may be associated with both gastrointestinal and neurologic symptoms in these patients. For this reason, one of the diseases in which FT is most investigated in neurological diseases is autism. Studies have reported that FT has shown successful results in both neurological and gastrointestinal symptoms in autistic children (36). In a study involving patients with immunosuppressive (glucocorticoid, 6-mercaptopurine, receiving azothiopurine), biologic agents (infliximab, adalimumab), immunocompromised (renal transplantation, lymphoma, chronic lymphocytic leukemia) patients were found to be effective in FT 20 patients (37).

Perhaps the most important advantage of fecal transplantation is the lack of donor disease. It is a safe, cheap and low-tech operation. There is no risk of rejection, the risk of infection is very low and immunosuppressive treatment is not required. Fecal transplantation breaks the cycle of repeated antibiotic use, thus ensuring the continuity or renewal of the intestinal 
flora. Another advantage of fecal transplantation is the ability to initiate treatment of enteric infections without the need for pathogen identification with the broad spectrum of fecal activity. As a matter of fact, Eiseman et al. In 1958, they reported the first case of pseudomembranous enterocolitis without knowing the cause (38). Side effects are generally not mentioned when working in the literature. In one study, temporary irritation due to nasogastric tube placement, sensation of rectal discomfort in colonoscopy, gas, nausea and bloating were reported $(24,39)$. One of the main potential risks is the transfer of infectious agents outside the donor to the recipient (40). This risk is reduced by selecting the selected donors from the near-physical vicinity of the recipient. Other side effects reported were upper gastrointesinal hemorrhage, irritable bowel disease indication, infectious irritable bowel disease indication, constipation, not direct fecal necrosis $(39,41,42)$.

Today, we do not have enough information about the longterm results of this method. Especially with FT, it is thought that the knowledge about infections, inflammation, GIS malignancies is missing. Moreover, immunosuppressive therapy, GIS malignancies, chemotherapy/radiotherapy, active HIV, HBV, HCV infection, IV drug addicts, tattooing/piercing cases, multiple sexual partners, and homosexuality are also shown as cases where FT is contraindicated.

In conclusion, If we think that our microbiota fingerprint is a unique organ for each person, such as the retina, the treatment of microbiota diseases will automatically differ itself from person to person. However, all of the characteristics such as age, donor selection, post-transplantation process management, environmental factors, especially the illnesses carried by the recipient and the donor, the amount of drug in the preparation process and the content to be transplanted are all indicative of how individualized treatment of fecal transplantation is.

As we get to know intestinal microbiota better, it will be revealed that there are many diseases that we do not know pathogenesis today. The main drawback of this treatment is that there are very few randomized controlled trials. We do not have enough knowledge about the results in the long run, but there is a need for long-term controlled work. Fecal transplantation appears to be highly effective and reliable in the treatment of recurrent $C$. difficile infection and pseudomembranous enterocolitis, although there is no specific standardization in practice. It is quite low cost compared to other treatment regimens. This is another of the factors that show how convenient and usable FT is in person-specific treatment modalities. The FT may in future be used as a therapeutic agent in $C$. difficile infection in the form of a capsule containing selected bacterial species, or even in disorders of the gastrointestinal tract known as idiopathic nowadays.

While intestinal microbiota has been a closed box for researchers in the past, astonishing results have emerged as astonishing results as microbiota studies have increased in recent years. In light of these results, the importance of microorganisms in the gastrointestinal tract has begun to be better understood. With the increase in studies on intestinal microbiota, it is now becoming possible that microbiota can be used as a therapeutic modality and the FT approach has emerged. Research on intestinal microorganisms, known to function in a wide range from inflammatory bowel disease and irritable bowel syndrome to fibromyalgia and even autism, It is thought that the fog of disease on diseases that we do not have clear information about pathogenesis is going to happen. These results indicate that FT is rapidly gaining popularity in non-gastrointestinal diseases and will be mentioned more frequently in the coming years.

The study is noninvasive and we didn't make a drug application so we didn't take an ethical approved.

Author Contributions: Concept - E.C., A.C.D.; Design - F.I., E.P.Y.; Supervision - E.C., C.H.O.; Resources - E.C., C.H.O.; Materials - F.I., E.P.Y., H.A., S.T., A.Y.; Data Collection and/or Processing - E.P.Y., H.A., S.T., A.Y.; Analysis and/or Interpretation - E.C., C.H.O., E.P.Y.; Literature Search - H.A., S.T., A.Y.; Writing Manuscript - E.C.; Critical Review - E.C., C.H.O., A.C.D.

Conflict of Interest: The authors have no conflicts of interest to declare.

Financial Disclosure: The authors declared that this study has received no financial support.

Peer-review: Externally peer-reviewed.

Yazar Katkıları: Fikir - E.C., A.C.D..; Tasarım - F.I., E.P.Y.; Denetleme - E.C., C.H.O.; Kaynaklar - E.C., C.H.O.; Malzemeler - F.I., E.P.Y., H.A., S.T., A.Y.; Veri Toplanması ve/veya İşlemesi - E.P.Y., H.A., S.T., A.Y.; Analiz ve/veya Yorum - E.C., C.H.O., E.P.Y.; Literatür Taraması - H.A., S.T., A.Y.; Yazıyı Yazan - E.C.; Eleştirel İnceleme - E.C., C.H.O., A.C.D.

Çıkar Çatışması: Yazarlar çıkar çatışması bildirmemişlerdir.

Finansal Destek: Yazarlar bu çalışma için finansal destek almadıklarını beyan etmişlerdir.

Hakem Değerlendirmesi: Dış bağımsız.

\section{References}

1. Sullivan A, Edlund C, Nord CE. Effect of antimicrobial agents on the ecological balance of human microflora. Lancet Infect Dis 2001; 1: 101-14. [CrossRef]

2. Duncan SH, Lobley GE, Holtrop G, Ince J, Johnstone AM, Louis $\mathrm{P}$, et al. Human colonic microbiota associated with diet, obesity and weight loss. Int J Obes (Lond) 2008; 32: 1720-4. [CrossRef]

3. Koren O, Spor A, Felin J, Fåk F, Stombaugh J, Tremaroli V, et al. Human oral, gut, and plaque microbiota in patients with atherosclerosis. Proc Natl Acad Sci U S A 2011; 108: 4592-8. [CrossRef]

4. Kau AL, Ahern PP, Griffin NW, Goodman AL, Gordon JI. Human nutrition, the gut microbiome and the immune system. Nature 2011; 474: 327-36. [CrossRef] 
5. Ley RE. Obesity and the human microbiome. Curr Opin Gastroenterol 2010; 26: 5-11. [CrossRef]

6. Seema Maroo, J. Thomas Lamont. Recurrent Clostridium Difficile. Gastroenterology 2006; 130: 1311-6. [CrossRef]

7. Aas J1, Gessert CE, Bakken JS. Recurrent Clostridium difficile colitis: case series involving 18 patients treated with donor stool administered via a nasogastric tube. Clin Infect Dis 2003; 36: 580-5. [CrossRef]

8. Smits LP, Bouter KE, de Vos WM, Borody TJ, Nieuwdorp M. Therapeutic potential of fecal microbiota transplantation. Gastroenterology 2013; 145: 946-53. [CrossRef]

9. Van Nood E, Vrieze A, Nieuwdorp M, Fuentes S, Zoetendal EG, de Vos WM, et al. Duodenal infusion of donor feces for recurrent Clostridium difficile. N Engl J Med 2013; 368: 407-15. [CrossRef]

10. Bakken JS, Borody T, Brandt LJ, Brill JV, Demarco DC, Franzos MA, et al. Treating Clostridium difficile infection with fecal microbiota transplantation. Clin Gastroenterol Hepatol 2011; 9: 1044-9. [CrossRef]

11. Gough E, Shaikh H, Manges AR. Systematic review of intestinal microbiota transplantation (fecal bacteriotherapy) for recurrent Clostridium difficile infection. Clin Infect Dis 2011; 53: 994-1002. [CrossRef]

12. Russell G, Kaplan J, Ferraro M, Michelow IC. Pediatrics 2010 Jun 14. doi: 10.1542/peds.2009-3363. [CrossRef]

13. Arumugam M, Raes J, Pelletier E, Le Paslier D, Yamada T, Mende DR, et al. Enterotypes of the human gut microbiome. Nature 2011; 473: 174-80. [CrossRef]

14. Landy J, Al-Hassi HO, McLaughlin SD, Walker AW, Ciclitira PJ, Nicholls RJ, et al. Review article: faecal transplantation therapy for gastrointestinal disease. Aliment Pharmacol Ther 2011; 34: 409-15. [CrossRef]

15. Schwan A, Sjölin S, Trottestam U, Aronsson B. Relapsing Clostridium difficile enterocolitis cured by rectal infusion of homologous faeces. Scand J Infect Dis 1984; 16: 211-5 [CrossRef]

16. Gustafsson A, Lund-Tonnesn S, Berstad A, Midtvedt T, Norin E. Faecal short-chain fatty acids in patients with antibioticassociated diarrhoea, before and after faecal enema treatment. Scand J Gastroenterol 1998; 33: 721-7. [CrossRef]

17. Garborg K, Waagsbø B, Stallemo A, Matre J, Sundøy A. Results of faecal donor instillation therapy for recurrent Clostridium difficile -associated diarrhoea. Scand J Infect Dis 2010; 42: 857-61. [CrossRef]

18. Aroniadis OC, Brandt LJ. Fecal microbiota transplantation: past, present and future. Curr Opin Gastroenterol 2013; 29: 79-84. [CrossRef]

19. Tvede M, Rask-Madsen J. Bacteriotherapy for chronic relapsing Clostridium difficile diarrhoea in six patients. Lancet 1989; 1: 1156-60. [CrossRef]

20. Borody TJ, Campbell J. Fecal microbiota transplantation: techniques, applications, and issues. Gastroenterol Clin North Am 2012; 41: 781-803. [CrossRef]

21. Brandt LJ, Aroniadis OC. An overview of fecal microbiota transplantation: techniques, indications, and outcomes. Gastrointest Endosc 2013; 78: 240-9. [CrossRef]

22. Van Nood E, Speelman P, Kuijper EJ, Keller JJ. Struggling with recurrent Clostridium difficile infections: is donor faeces the solution? Euro Surveill 2009; 14: pii: 19316. [CrossRef]

23. Rohlke F. Surawicz, CM, Stollman N. Fecal flora reconstitution for recurrent Clostridium difficile infection: results and methodology. J Clin Gastroenterol 2010; 44: 567-70. [CrossRef]
24. Xu MQ, Cao HL, Wang WQ, Wang S, Cao XC, Yan F, Wang BM. Fecal microbiota transplantation broadening its application beyond intestinal disorders. World J Gastroenterol 2015; 21: 102-11 [CrossRef]

25. de Theije CG, Wopereis H, Ramadan M, van Eijndthoven T, Lambert J, Knol J et al. Altered gut microbiota and activity in a murine model of autism spectrum disorders. Brain Behav Immun 2014; 37: 197-206 [CrossRef]

26. de Theije CG, Koelink PJ, Korte-Bouws GA, Lopes da Silva S, Korte SM, Olivier B et al. Intestinal inflammation in a murine model of autism spectrum disorders. Brain, Behavior, and Immunity 2014; 37: 240-247. [CrossRef]

27. Finegold SM, Molitoris D, Song Y, Liu C, Vaisanen ML, Bolte E, et al. Gastrointestinal Microflora Studies in Late-Onset Autism. Clin Infect Dis. 2002; 35: 6-16. [CrossRef]

28. Song Y, Liu C, Finegold SM. Real-time PCR quantitation of clostridia in feces of autistic children. Appl Environ Microbiol 2004; 70: 6459-65. [CrossRef]

29. Ananthaswamy A. Faecal transplant eases symptoms of Parkinson's disease. NewScience 2011; 209: 8-9. [CrossRef]

30. Borody TJ, Warren EF, Leis S, et al. Treatment of ulcerative colitis using fecal bacteriotherapy. J Clin Gastroenterol 2003; 37: 42-7. [CrossRef]

31. Grehan MJ, Borody TJ, Leis SM, Campbell J, Mitchell H, Wettstein A. Durable alteration of the colonic microbiota by the administration of donor fecal flora. J Clin Gastroenterol 2010; 44: 551-61. [CrossRef]

32. Vrieze A, Vrieze A1, Van Nood E, Holleman F, Salojärvi J, Kootte RS, Bartelsman JF, et al. Metabolic effects of transplanting gut microbiota from lean donors to subjects with metabolic syndrome. Gastroenterology 2012; 143: 913-6. [CrossRef]

33. Giada De Palma, Michael D. J. Lynch, Jun Lu, Vi T. Dang, Yikang Deng, et al. Transplantation of fecal microbiota from patients with irritable bowel syndrome alters gut function and behavior in recipient mice. Science Translational Medicine 2017; DOI: DOI: 10.1126/scitranslmed.aaf6397 [CrossRef]

34. Andrews P, Borody TJ, Shortis NP, Thompson S. Bacteriotherapy for chronic constipation- long term follow-up. Gastroenterology 1995; DOI: https://doi.org/10.1016/00165085(95)26563-5 [CrossRef]

35. Frye RE, Slattery J, MacFabe DF, Allen-Vercoe E, Parker W, Rodakis J, et al. Approaches to studying and manipulating the enteric microbiome to improve autism symptoms. Microb Ecol Health Dis. 2015; DOI: 10.3402/mehd. v26.26878 [CrossRef]

36. Finegold SM, Dowd SE, Gontcharova V, Liu C, Henley KE, Wolcott RD, et al. Pyrosequencing study of fecal microflora of autistic and control children. Anaerobe 2010; 16: 444-53. [CrossRef]

37. Brandt LJ, Aroniadis OC, Mellow M, Kanatzar A, Kelly C, Park T, et al. Long-term follow-up of colonoscopic fecal microbiota transplant for recurrent Clostridium difficile infection. Am J Gastroenterol 2012; 107: 1079-87. [CrossRef]

38. Eiseman B, Silen W, Bascom GS, Kauvar AJ. Fecal enema as an adjunct in the treatment of pseudomembranous enterocolitis. Surgery 1958; 44: 854-9.

39. Wettstein A, Borody TJ, Leis S, et al. Fecal bacteriotherapy: an effective treatment for relapsing symptomatic Clostridium difficile infection. In: 15th United European Gastroenterology Week 2007 (France). Vienna, Austria: United European Gastroenterology Federation, 2007. 
40. Waldum HL. Treatment with homologous feces. Tidsskr Nor Laegeforen 1998; 118: 1604-5.

41. Jorup-Rönström C, Hakanson A, Persson AK, Midtvedt T, Norin E. Feces culture successful therapy in Clostridium difficile diarrhea. Lakartidningen 2006; 103: 3603-5.
42. Louie TJ, Emery J, Krulicki W, Byrne B, Mah M. OPT-80 eliminates Clostridium difficile and is sparing of bacteroides species during treatment of C. Difficile infection. Antimicrob Agents Chemother 2009; 53: 261-3. [CrossRef] 